\title{
Dispute Resolution Through Mediation Can Reduce Case Deposits in Court
}

\author{
Muhammad Hatta \\ \{muhammad.hatta@unimal.ac.id\} \\ Departement of Law, Universitas Malikussaleh, Aceh, Indonesia
}

\begin{abstract}
Indonesian judges are considered incapable of resolving disputes quickly so that many cases accumulate in court every year. Mediation is one of the Alternative Dispute Resolutions that are considered to help in reducing the burden on the accumulation of cases in court. Mediation has advantages such as mediation carried out on sincere and sincere intentions, closed and confidential mediation forums, all parties can actively participate, flexible procedures, mediators are selected by mutual agreement and the decisions taken do not harm either party (win-win solution). Under this approach, dispute resolution through mediation is faster and more economical with success rates of 80-90 percent. Although there are some courts in Indonesia classified as successful in mediation, such as the District Court of Depok by 25 percent and the North Jakarta Religious Court account for 70 percent of all cases that go to the court. However, the use of mediation in Indonesia is still relatively low at 4 percent of all cases admitted in court. In order for mediation to be effective, the government must reform several laws related to dispute resolution both in court and out of court.
\end{abstract}

Keywords: Mediation, Reduce, Stacking, Case, Court.

\section{INTRODUCTION}

Common conflicts or disputes occur and can not be separated in the historical development of human life. Almost all people, organizations, professions and even countries have experienced conflict both internally and externally [1], [2]. Generally, all disputes are resolved by court (litigation). However, dispute resolution through courts has many disadvantages. For example, dispute settlement through courts takes a very long time and need a lot of money to take care of their case in court [3].

As a result of the lengthy settlement of the trial in court, many cases have accumulated in court. For example, in 2016, the number of cases accumulated in the Supreme Court increased was 2,357 cases [4]. If it is classified by type of case, for example in 2016, the number of cases accumulated in the Supreme Court is 1,006 civil cases, 311 criminal cases, 124 special civil cases, 717 special criminal cases, 131 military criminal cases, 68 state administrative cases [4].

The accumulation of cases is not only happening in Indonesia, but also occurs in developed countries such as the United States, United Kingdom, Australia and Canada [5], [6]. 
To reduce the accumulation of cases in the courts, all of these countries, including Indonesia, implement faster and more economical alternative dispute resolution mechanisms such as mediation, arbitration, consultation, negotiation and conciliation.

According to Nolan-Haley, Alternative Dispute Resolution is an umbrella term which refers generally to alternative adjudication of disputes such as negotiation, mediation, arbitration, mini-trial and summary jury trial [7]. From those alternative dispute resolution methods, mediation is one of the more effective and efficient mechanisms for resolving disputes both in court and out of court. However, the problem is whether mediation can be applied to all cases, whether court or out of court? What are the advantages or advantages of mediation so as to minimize the accumulation of cases in court.

\section{Research Method}

This study is a qualitative research using normative juridical approach. This study is legalistic or doctrinal using analytical techniques substance. Content analysis technique is a research carried out systematically by analyzing a legal document pertaining to dispute resolution through mediation mechanism [8], [9]. The aim of the study is to find, explain, research, analyze and propose a systematic way of facts, principles, concepts, theories, certain laws and law enforcement institutions that find knowledge and new ideas for suggested be a change or renewal [10]. Doctrinal research is also a purely theoretical research, documentation or theoretical research in which the necessary data is sourced from libraries or other scientific databases [11].

\section{Mediation In Indonesia}

\subsection{Mediation in the Civil Court}

In the legal aspect, all civil cases such as copyright disputes and intellectual property rights, business competition, workers' dismissals, environmental pollution, medical disputes and others must be resolved through mediation before the dispute settles through the courts. Typically, the mediation is facilitated by the court and the mediator is one of the judges or other parties referred by the judge in charge of the dispute concerned. If in the mediation process the parties do not reach an agreement then the dispute will proceed to the next stage that is resolved through the court in accordance with the Book of Civil Procedure Code.

The mechanism mentioned above is called mediation in the court which means dispute resolution through mediation between the parties in court. Before the principal investigation process begins, the judicial panel provides an opportunity for the parties to the dispute to settle the case through mediation and the court facilitates the mediation process. If the mediation proceeds smoothly and the parties have made an agreement then the judicial process can be terminated in accordance with the agreement of both parties. The mediation in the court system is similar to the court-annexed mediation system. However, the mechanism of courtannexed mediation is conducted when the case is being tried in court. The judge may allow the parties to the dispute to settle the case through a mediating mechanism if both parties are willing [12]. 
In Indonesia, the system of mediation in the court or court-annexed mediation has long been implemented since the Dutch colonial period. This system has been regulated in the Het Herziene Indonesich Reglement (HIR, Staatblad 1941: 44), Rechtsreglement Buitengewesten (R.Bg, Staatsblad, 1927: 27) and Reglement op de Rechtsvordering (Rv, Staatsblad 1874: 52) [13]. In Articles 130 and 154 of the Indonesian Criminal Code (KUHPdt), it is determined that mediation in courts can be made against civil cases only. All mediation decisions are made in written form and established by the court. To ensure that both parties do not forward their case to court, in the mediation decision it should be mentioned that this case has been completed and no longer forwarded to court. All civil cases are required to follow the mediation and mediation process before the judges conduct the principal review of the case. If the parties do not find a solution or a solution to their dispute then the case proceeds to the process of resignation.

Currently, Indonesia has issued Law No. 30 of 1999 on Arbitration and Alternative Dispute Resolution. The law can serve as a basis for mediation through courts (litigation) and outside the court (non litigation). However, dispute resolution through courts has been issued Regulation of the Supreme Court (Perma) No. 1 of 2016 on Court Mediation Procedures. Under this rule, all judges, mediators and parties to the dispute must know and understand the rules to facilitate or expedite the mediation process in court.

\subsection{Criminal Cases Settlement through Mediation: Is it Possible?}

Generally, mediation can only be applied to civil cases only, whereas in criminal cases, mediation is not applicable. All criminal cases are submitted and resolved by the state through its law enforcement apparatus [14]. However, the many advantages found in dispute resolution through mediation, mediation was introduced and applied to criminal cases with penal mediation term. According to Rudi Satrio, there are several criminal cases that are difficult to resolve through the courts but more effective if the case is resolved through mediation, for example, a case involving many times such as brawl between villages, tribes and schools [15].

In the aspect of settlement of criminal cases, the concept of mediation or other types of alternative dispute resolution is called the concept of restorative justice that places the judiciary as mediator. The concept of restorative justice is a new term for the old concept. Restorative justice approaches have been used in solving conflicts between the parties and restoring peace in the community. Because retributive or rehabilitative approaches to crime in recent years are considered unsatisfactory. Therefore it causes the urge to move to a restorative justice approach involves perpetrators, victims and communities in an effort to create a balance between perpetrators and victims [16].

At the 10th United Nations Congress on the Prevention of Crime and the Treatment of Offenders held in Vienna, 10-17 April 2000, restorative justice was seen as an alternative model of criminal justice [17], [18]. Where all parties take part to solve certain problems together how to deal with the consequences of the problem and its implications for the future. In this model, the emphasis is on reparation and prevention rather than imposing a criminal. This restorative justice and other forms of dispute resolution (formal and semi-formal dispute resolution) reflect the present tendencies of individualism and diminish the functioning of the state.

Basically, mediation in the settlement of criminal cases is not recognized in the provisions of the law regarding the criminal justice system. Law No. 8 of 1981 on Criminal Procedure Code and Law No. 2 of 2002 on the Police of the Republic of Indonesia as the legal basis for the police to enforce the law against the perpetrators of criminal acts does not regulate 
mediation as an alternative to the settlement of criminal cases. In both laws, it is even implied that there is no peace in the settlement of criminal cases and if the achievement of peace among the parties does not eliminate the existing criminal elements.

However, in recent developments shows that Indonesia is gradually beginning to introduce mediation to resolve criminal cases through customary justice. For example, the Government of Aceh has issued the Regional Regulation (Qanun) No. 7 of 2000 on the Implementation of Indigenous Life, which authorizes customary courts to reconcile through negotiations to resolve customary violations such as theft, nasty deeds, minor maltreatment, fights and others. The settlement of criminal cases through customary court by using mediation is also carried out in various regions such as Padang, Bali, South Sulawesi and other areas.

Currently, penal mediation has started to take shape formally, especially after the issuance of Chief of Police No. Pol: B / 3022 / XII / 2009 / SDEOPS 14 December 2009 on Case Handling through Alternative Dispute Resolution (ADR). This letter is partial and the principles of penal mediation referred to in this Chief of Police emphasize that the settlement of criminal cases by using ADR, must be agreed by the litigants but if no new agreement is settled in accordance with the legal procedures that apply professionally and proportionally.

However, juridically, mediation cannot be implemented against in criminal cases because there is no law regulating it. If mediation is used as an alternative in solving criminal cases, it must be amended first Law No. 8 of 1981 on the Criminal Procedure Code as the foundation for the police to enforce the law against the perpetrators of criminal acts. In addition, the mediation of criminal cases should be limited to criminal offenses involving mass forces, criminal cases of humanitarian considerations and prioritizing coaching, traffic accidents cases, public concerns and minor criminal offenses, where the consequences of the criminal act are very light [17], [18].

\section{Mediation Can Reduce Stackage Of Cases In Courts}

In general, the court is still the ideal place to seek and find justice. All disputes, cases or cases occurring in the life of the public both criminal and civil aspects will be tried in court in accordance with their powers. However, nowadays, the dispute resolution through the court has been heavily criticized and the negative responses to the court settlement usually take a very long time and spend cost a lot. This is due to the fact that the number of cases that go to court more than the number of judges who tried these cases, resulting in many cases that accumulate in court every year.

For example, In 2013, the number of cases registered in the Supreme Court was 22,449 cases, but only 16,034 cases were completed, so the cases that accumulated in the Supreme Court is 6,415 cases [19]. In 2014, there were 18,926 cases that reached the Supreme Court, but only 16,034 cases were finalized, resulting in an unfinished number of cases and 2,892 cases in the Supreme Court [20]. In 2015 also, the number of cases registered in the Supreme Court as many as 18,402 cases, but the trial only 3,950 cases alone, so that cases that accumulate in the Supreme Court as many as 14,452 cases [21]. Whereas, in 2016, the number of cases that reached the Supreme Court of 18,580 cases, but only 16,223 cases completed, so the number of cases that are not resolved amounted to 2,357 cases [4]. 


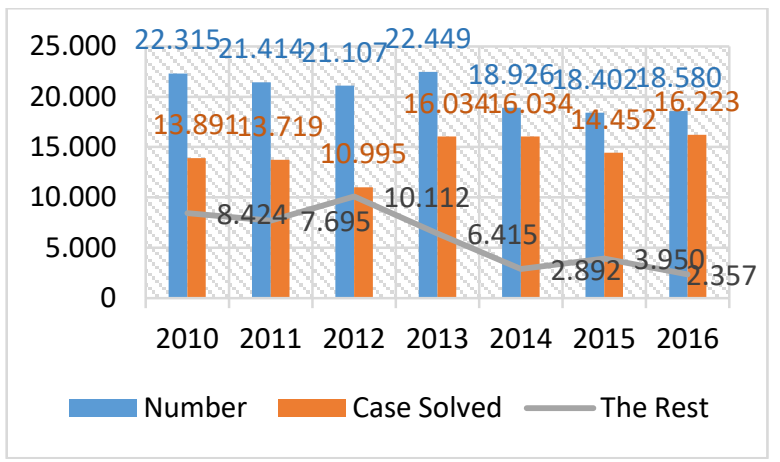

Fig. 1 Stacking of Cases in Courts from 2010-2016

The failure of the courts to resolve and reduce the stack of cases in court has caused disappointment and reduced the confidence of the disputants to bring their case to court. However, this fact is not a new issue and not just in Indonesia that there is accumulation of cases in court but the issue of accumulation of cases in court also occurred in other countries. For example, in 2009, civil cases filed in the Malaysian High Court was 44,873 cases, but only 23,272 cases and 21,601 cases were raised. In 2010, the number of cases that went to the High Court amounted to 9,734 cases, however, only 5,061 cases were resolved, resulting in 4,673 cases [22].

The length of time required to settle a dispute in court may cause harm to the parties to the dispute both material and immaterial damages. Abraham Lincoln states that the parties to the dispute are not encouraged to bring the case to be resolved in court as a litigation settlement can provide harm to both parties. For example, if a person who is declared victorious in his case in court, then in essence, the party loses because it has a lot of time and spends a lot of money to take care of his case in court [23].

Disillusionment with the court system has led to the increased public interest in resolving disputes through alternative dispute resolution. Freedman \& Prigoff mentioned that alternative dispute resolution was in demand due to dissatisfaction with court performance in resolving disputes in the community [24]. The approach widely used in alternative dispute resolution mechanisms is mediation by appointing parties third as a mediator to lead the dispute resolution process between the parties [25].

In the Indonesian justice system, the position of mediation is to help the courts resolve disputes that have been registered in court so as to reduce the accumulation of cases in court. Mediation does not remove the position, function and role of the court. However, not all disputes or cases that occur in the community can be resolved through mediation. The parties who want to resolve their dispute through mediation must meet the various criteria that have been determined by the existing law.

The dispute resolution through mediation provides equal opportunities to the disputing parties to be actively involved in a negotiating forum to find a solution to the dispute being faced without putting forth the wrong side as well as the correct party. This negotiation forum is led by an independent mediator who has extensive knowledge of the issues at hand. If the mediator and the parties to the dispute can understand the mediation mechanism correctly, then many goodnesses and prosperities are found in solving various cases in both criminal and civil cases. According to MacFarlane, among the advantages contained in dispute resolution through mediation is that mediation does not waste much time, not expensive, can reduce the 
psychological burden, avoid hostilities, so that the relationship of the parties to the dispute still be well-established [26].

The advantages of dispute resolution through mediation do not have a formal proofing procedure, so mediation process can be done simply, quickly and not cost much [24]. Usually, the most time needed in the dispute resolution process through the courts is the evidentiary process. Many warring parties carry documents and present witnesses to corroborate their claims or defend their arguments. The longer the court verification process, the more costs will be required as the parties to the dispute must increase the cost of their lawyers and pay the accommodation costs of the witnesses presented in court.

According to the American Bar Association, mediators are not bound by standard procedures such as dispute settlement in court. The mediator is free to determine what mechanism he considers appropriate to the case he is handling. One of the most important things is that the mediator must be able to create a comfortable mediation forum so that the parties to the dispute can think quietly and can produce acceptable decisions and satisfy all parties. The mediator must know and understand all stages of mediation if the mediator finds either party imposing coercion, dishonesty, fraud or unbalanced position, the mediator is entitled to stop the mediation process [27].

McAdoo \& Welsh emphasized that in order to make mediation proceed effectively and efficiently, the parties to the dispute must have a competent and fair mediator in running the mediation [28]. According to Moore, competent mediators will guide the mediation process more quickly and appropriately. The job of a mediator should examine, analyze and simplify the dispute he is currently engaged in and offer several approaches to resolving disputes between the two disputants [29].

The advantage of dispute resolution through mediation is to use a win-win approach. This approach positions the parties in the mediation negotiation forum to feel won or no one is harmed. All things that are still incriminating one of the parties will be discussed and sought solutions to lighten the burden of both parties so as to avoid hostility between the parties to the dispute [30].

Dispute resolution mechanisms through mediation are confidential and closed. The parties to the dispute do not have to worry about their reputation and reputation will be damaged because the mediator is obliged to keep all the facts, documents and identities of the parties to the dispute. All the parties to the dispute can determine or choose which approach is used in resolving disputes between the two parties. In the mediation process there is no coercion, but mediation is conducted on the basis of honesty and sincerity [31]. Another advantage of mediation is to maintain and keep good relationships between the parties to the dispute because mediation does not put the disputing parties as winners and losers, but both parties will have a benefit and win the same (win-win solution).

Based on the Perma Number 1 of 2016 dated 3 February 2016 on Mediation Procedures in the Court, the period of time required to resolve the dispute is 30 days and if necessary it can be extended for another 30 days. The process of dispute resolution through mediation is very fast. This is very different from the process of dispute resolution through courts that can take years for years. According to former Malaysian Supreme Court, Tun Arifin Zakaria mentioned that mediation can help the court to decrease the accumulation of cases in court. Disputes among the parties can be resolved quickly if parties have the desire and sincerity to resolve their disputes without coercion of the parties [32].

The many advantages of mediation mentioned above can provide satisfaction to the parties to the dispute. There are some courts in Indonesia that have achievements in mediation, for example in 2013, Cibinong District Court succeeded in mediating 67 cases out of 367 civil 
cases entering court. In 2015, the success rate of mediation at the Depok District Court was 25 percent of all mediated cases and the success rate of mediation in the North Jakarta Religious Court reached 70 percent. In addition, the Central Jakarta District Court, successfully mediate the case of PT. Petrowidada with PT. Indonesia's Leasing Lease with US \$ 37.6 million involving foreign parties, such as businessmen from Japan and South Korea [33].

However, nationally the use of mediation as an alternative mechanism to solve cases is still relatively low. According to the Deputy Coordinator of the Supreme Court Justice Reform Working Group, Takdir Rahmadi, many cases are trying to resolve the case through a new 4 percent mediation that reached a peace agreement [34]. This is much different from the overseas mediation, the success rate reaches 80-90 percent [35], [36]. For example, the mediation run by Community Justice Center (CJC) in the state of New South Wales, Australia reaches $80 \%$ [37]. In addition, Indonesia has no valid data on the success of mediation nationally. Even though, the data is important to obtain, at least, to measure the extent of effectiveness of mediation in Indonesia.

\section{Conclusions}

Dispute resolution is generally done by two methods, namely litigation and alternative dispute resolution. However, in global developments, dispute resolution through courts began to be abandoned. Courts that are the only places where seeking justice are not effective. Disputes prosecuted in court are slow and require enormous expenses to take care of cases in court. As a result, there were many cases of court accidents in both the District Court, High Court and the Supreme Court.

One type of alternative dispute resolution method that has the potential to resolve disputes more quickly and economically is mediation. In mediation, the positions of the disputing parties are the same, no parties feel compelled or oppressed, the mediation forum is closed and confidential. In the mediation process, negotiations are led by a competent, neutral and elected mediator and agreed upon by both parties to the dispute. In addition, the advantage of dispute settlement through mediation is based on sincere and sincere intentions and the approach used is that all parties feel (win-win solution).

In the legal aspects of Indonesia, mediation can be applied to all civil cases. However, in the criminal case still exist cross-references. There are some people who allow mediation as an alternative to the settlement of criminal cases but also some others who disagree as peace does not abolish its criminal acts. However, in the process of criminal penalty subscription, the police often make peaceful efforts before the investigation and investigation process is carried out. This article suggests, to avoid differences of opinion on the legality of the mediation of criminal cases, it is necessary to make changes to the Law No. 8 of 1981 on the Criminal Procedure Code.

Many advantages of mediation in resolving disputes have given hope to the disenchanted community to the performance of the courts so that the public is more interested in resolving the dispute outside the court through negotiations led by an independent and neutral mediator. Although in some courts in Indonesia, mediation has helped to reduce the accumulation of cases in court. For example, In 2015, the level of successful mediation in the Depok District Court was 25 percent of all mediated cases. However, nationally the use of mediation as an alternative mechanism to resolve cases is still relatively low at only 4 percent. 


\section{References}

[1] W. H. Othman, "Konfiik Keluarga dan Intervensi," Serdang-Malaysia, 1990.

[2] L. Boulle, Mediation-Skills \& Techniques. Australia: Butterworths, 2001.

[3] A. A. Aziz, S. M. Isa, S. S. A. Yusoff, and T. C. Ong, "Towards harmonisation of the ASEAN Contract Law: The legal treatment of unfair consumer contract terms among selected ASEAN member states," Asian J. Account. Gov., vol. 2, pp. 61-65, 2011.

[4] Mahkamah Agung RI, "Laporan Tahunan Mahkamah Agung RI Tahun 2016," Jakarta, 2017.

[5] M. Hanks, "Perspectives on Mandatory Mediation," Univ. N. S. W. Law J., vol. 35, no. November 1950, pp. 929-953, 2012.

[6] A. Othman, "Introducing Alternative Dispute Resolution in Malaysia: Prospects and Challenges," Malayan Law J., vol. 2, p. ccxxiv, 2002.

[7] J. M. Nolan-Haley, "The Merger of Law and Mediation: Lessons From Equity Jurisprudence And Roscoe Pound," Cardozo J. Confl. Resolut., vol. 6, p. 57, 2004.

[8] J. Van Maanen, "Reclaiming Qualitative Methods for Organizational Research: Preface," Adm. Sci. Q., vol. 24, pp. 520-526, 1979.

[9] G. . McCracken, The Long Interview. London: Sage, 1998.

[10] S. E. Rowe, "Legal Research, Legal Analysis, and Legal Writing: Putting Law School into Practice," SSRN eLibrary, vol. 1193, no. 2000, pp. 1-19, 2009.

[11] T. Hutchinson and N. Duncan, "Defining and Describing What We Do: Doctrinal Legal Research," Deakin Law Rev., vol. 17, pp. 83-119, 2012.

[12] S. R. Marsh, "Current Issues In Court Annexed Mediation," ADR Resources, 2000. .

[13] R. Tresna, Komentar Het Herziene Indonesich Reglement (HIR). Jakarta: Pradnya Paramita, 1979.

[14] S. Sianturi, Hukum Penitensia di Indonesia. Bandung: Alumni, 1996.

[15] B. N. Arief, "Penal Mediation dalam Penyelesaian Sengketa di Luar Mahkamah," Semarang, 2007.

[16] Muladi, Hak Asasi Manusia, Politik dan Sistem Peradilan Pidana. Semarang: Badan Penerbit Universitas Diponegoro, 1997.

[17] U. Al-Tamimi, "Lembaga Pemaafan Sebagai Alternatif Penyelesaian Perkara Pidana Perspektif Hukum Islam,” J. Diskurs. Islam, vol. 1, no. 3, p. 453, 2013.

[18] H. Y. \& S. Basri, "Model Penyelesaian Alternatif Perkara Pidana Pembunuhan Biasa menurut Hukum Islam dan Relevansinya dengan Pembaharuan Hukum Pidana Indonesia," J. Huk. Ius Quia Iustum Law, vol. 24, no. 1, pp. 73-93, 2016.

[19] Mahkamah Agung RI, "Laporan tahunan mahkamah agung republik indonesia 2013," Jakarta, 2014.

[20] Mahkamah Agung RI, "Laporan Tahunan Mahkamah Agung RI Tahun 2014," Jakarta, 2015.

[21] Mahkamah Agung RI, "Laporan Tahunan Mahkamah Agung RI Tahun 2015," Jakarta, 2016.

[22] Hamidah, "Sumbangan Dan Peranan Mahkamah Dalam Perkembangan EMahkamah," in Persidangan Meja Bulat Transformasi Mekanisme Penyelesaian Pertikaian Ke Arah Keadilan Sosial: Peranan E-Mahkamah, 2011, 14 July 20. 
[23] P. Lovenheim, Mediate, Don't Litigate: How to Resolve Disputes Quickly, Privately and Inexpensively Without Going to Court. New York: Mc. Graw-Hill, Inc, 1989.

[24] L. Freedman and M. Prigoff, "Confidentiality in Mediation: The Need for Protection," Ohio State J. Disput. Resolut., vol. 2, no. 1970, p. 37, 1987.

[25] S. Z. S. Hassan, Ilmu dan Autoriti: Pengalaman Sosial Seorang Kadi. Bangi: Institut Alam dan Tamadun Melayu, Universiti Kebangsaan Malaysia, 1994.

[26] J. MacFarlane, Rethingking Disputes: The Mediation Alternative. London: Cavendish Publishing Limited, 1997.

[27] American Bar Association, "Model Rules of Professional Conduct," American Bar Association, 2001. .

[28] B. McAdoo and N. A. Welsh, "Look before you leap and keep looking: lessons from the institutionalization of court-connected mediation," Nevada Law J., vol. 5, pp. 399432, 2004.

[29] C. W. Moore, The Mediation Process: Practical Strategies for Resolving Conflict, 3rd Editio. San Francisco: CA: Jossey-Bass, 1996.

[30] K. Bollen, M. Euwema, and L. Munduate, Advancing Workplace Mediation Through Integration of Theory and Practice. Belgium: Springer International Publishing, 2016.

[31] A. Douglas, "The Impact of Mediation on State Courts," Ohio State J. Dispiute Resolut., vol. 17, no. 3, pp. 627-640, 2002.

[32] Anonymous, "Ketua Hakim: Mediasi Mampu Kurangkan Kes Tertunggak," Malaysianbigest, 2014.

[33] Nay, "Mediasi (Bukan) Basa-Basi: Belum genap setahun pelaksanaan mediasi di pengadilan, berbagai cerita mengemuka. Banyak keluhan, namun terselip pula kisah sukses," hukum online, 2004. .

[34] A. Cholil, "Data Keberhasilan Mediasi Nasional Ditargetkan Tersedia Akhir Tahun 2017," Mahkamah Agung, 2017. .

[35] S. Szmania, "Alternative Dispute Resolution in Medical Malpractice: A Survey Of Emerging Trends and Practices," Confl. Resolut. Q, vol. 26, pp. 71-96, 2008.

[36] D. Sohn, "Medical malpractice reform: The role of alternative dispute resolution," Clin. Orthop. Relat. Res., vol. 470, no. 5, pp. 1370-1378, 2012.

[37] A. Cholil, "Mengapa Mediasi Begitu Sukses di Australia?," Pengadilan Agama Magelang, 2013. . 